Original Article

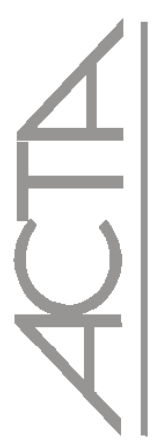

\title{
Burnout syndrome in senior undergraduate nursing*
}

\author{
Sindrome de Burnout em acadêmicos do último ano da graduação em enfermagem \\ Sindrome de Burnout en estudiantes del último año de graduación en enfermería
}

\section{Rayama de Oliveira ${ }^{1}$, Rita Catalina Aquino Caregnato² ${ }^{\text {, Sheila Gonçalves Câmara }}{ }^{3}$}

\begin{abstract}
Objective: This papers' goal was to evaluate the presence and the factors associated to Burnout Syndrome among senior year Nursing students. Methods: Exploratory descriptive quantitative research held in a private University of Rio Grande do Sul, with an intentional sample of 42 students enrolled in the 1st half of 2011, through the application of the instrument Burnout Inventory Student Survey (MBI-SS). The sample represented $76.3 \%$ of the population studied. Results: As for the burnout rates, it was found that the professional effectiveness was the amount that reached higher average index 5.03, followed by emotional exhaustion 3.26 and disbelief 1.57. Conclusion: Burnout syndrome was not identified among the participants, so that the factors associated with it were also not identified. The only finding was that the students who have children have less emotional exhaustion.
\end{abstract}

Keywords: Burnout professional; Stress psychological/nursing; Students nursing

\section{RESUMO}

Objetivo: Avaliar a presença e os fatores associados à Síndrome de Burnout entre acadêmicos cursando o último ano da graduação em Enfermagem. Métodos: Pesquisa de abordagem quantitativa, exploratória descritiva, realizada em uma Universidade privada da região metropolitana de Porto Alegre (Rio Grande do Sul), com amostra intencional de 42 estudantes dos sétimo e oitavo semestres, matriculados no $1^{\circ}$ semestre de 2011, por meio da aplicação do instrumento Burnout Inventory Student Survey. A amostra representou 76,3\% da população pesquisada. Resultados: Quanto aos índices de Burnout, verificou-se que a eficácia profissional foi a dimensão que atingiu maior índice médio (5,03), seguida pela exaustão emocional $(3,26)$ e descrença $(1,57)$. Conclusão: A Síndrome de Burnout não foi identificada entre os participantes, como também não foram reconhecidos fatores associados à mesma. Apenas observou-se que os acadêmicos com filhos possuem menor exaustão emocional. Descritores: Esgotamento profissional; Estresse psicológico/enfermagem; Estudantes de enfermagem

\section{RESUMEN}

Objetivo: Evaluar la presencia y los factores asociados al Síndrome de Burnout entre alumnos que cursan el último año del pregrado en Enfermería. Métodos: Investigación de abordaje cuantitativo, exploratorio descriptivo, realizado en una Universidad privada de la región metropolitana de Porto Alegre (Rio Grande do Sul), con una muestra por conveniencia de 42 estudiantes del séptimo y octavo semestre, matriculados en el 1er semestre del 2011, por medio de la aplicación del instrumento Burnout Inventory Student Survey. La muestra represento el 76,3\% de la población investigada. Resultados: En cuanto a los índices de Burnout, se verificó que la eficacia profesional fue la dimensión que alcanzó el mayor índice promedio (5,03), seguido por el cansancio emocional $(3,26)$ e incredulidad (1,57). Conclusión: El Síndrome de Burnout no fue identificado entre los participantes, así como también no fueron reconocidos los factores asociados a la misma. Apenas se observó que los estudiantes con hijos poseen menor cansancio emocional.

Descriptores: Agotamiento profesional; Estrés psicológico/enfermería; Estudiantes de enfermería

\footnotetext{
* Study performed in Nursing Undergraduate Course of Lutheran University of Brazil - ULBRA - Canoas (RS), Brazil.

${ }^{1}$ Nurse. Irmandade Santa Casa de Misericórdia of Porto Alegre - Porto Alegre (RS), Brazil.

${ }^{2}$ PhD in Education. Professor of Nursing Course and at Nursing Graduate Program, Lutheran University of Brazil - ULBRA - Canoas (RS), Brazil; Professor at Nursing Department, Federal University of Health Sciences of Porto Alegre - UFCSPA - Porto Alegre (RS), Brazil.

${ }^{3}$ PhD in Psychology. Professor of Psychology Course and Public Health Graduate Program, Lutheran University of Brazil - ULBRA - Canoas (RS), Brazil;

Professor of Psychology Department, Federal University of Health Sciences of Porto Alegre - UFCSPA - Porto Alegre (RS), Brazil.
} 


\section{INTRODUCTION}

In the capitalist world, the job market is increasingly demanding and competitive, making the daily work busy and stressful. Entering this market requires much more than a bachelor's degree; scientific and technological advances require the professional to be always up to date and prepared for changes. In consequence, bachelor's in nursing courses must be prepared to adapt their academic curricula to new trends in the job market. This constant change of scenery creates a more stressful factor on the undergraduate student journey ${ }^{(1)}$.

The bachelor's nursing program is theoretical and practical, with minimum workload of 4,000 hours, aiming at the training of the generalist, humanist and qualified nurse for the profession practice, able to work at all levels of health care, with training to promote the completeness health of the human being ${ }^{(2)}$.

Generally, courses covering the health area have a practical activity, in which students perceive the implications and limitations of their knowledge, when they practice. In early interventions with patients, doubts, fears and anxieties related to therapeutic practice usually emerge. Students come from a situation where the problems and difficulties of professional practice are not addressed or are treated as superficial, and knowledge gained seems appropriate to future situations of intervention, which is not confirmed in practical situations. Consequently, the worst concerns of the students are related to making a mistake, harming the client and not being recognized by classmates and professors ${ }^{(1,3)}$.

In this population, Burnout, refers to the feeling of exhaustion due to study demands and lack of theory and practice relationship, experiencing a sense of depersonalization and a sense of no personal accomplishment, ie, education does not give useful learning for professional training ${ }^{(4,5)}$. The burnout syndrome has been considered a social problem of great relevance and has been studied in many countries ${ }^{(5)}$. For the first time, Burnout, a term coined by Freudenberger in 1974 to describe the physical and mental state of young people who voluntarily worked and provided services in a rehab clinic. In a short period of time, these young people started having fatigue, irritability and started avoiding their patients ${ }^{(6,7)}$.

Syndrome is a phenomenon characterized by a set of signs and symptoms of various causes and it can be physical or psychological and, variably, psychophysical; whereas the term Burnout, word of English origin, means, "burning to the outside". It is a syndrome of the work environment, characterized by a process of chronicity response to occupational stress, leading to decreased productivity and quality in work-related activities and studies, when handling methods fail or are insufficient, bringing negative consequences to the individual, such as in professional, familiar and social aspects ${ }^{(7-11)}$.

The first publication on the syndrome in Brazil occurred in 1987 in the Brazilian Journal of Medicine. In the 1990s, the first theses and other publications began to appear, alerting some professional about it. In May 1996, the burnout syndrome was included in ICD10, Annex II, group V, in Pathogens Agents causing occupational diseases ${ }^{(12)}$. Conversely, this illness is still unknown, even by some professionals who diagnosis it, by professionals who suffer from this syndrome, and others who deal directly with interpersonal relationships. Eventually, people with Burnout are treated as suffering from stress or depression, harming them with wrong treatments, because the root of the cause is not faced ${ }^{(12)}$.

Symptoms found can be grouped in four areas: psychosomatic, behavioral, emotional and defensive. The psychosomatic symptoms are: the onset of migraines, muscle tension, gastrointestinal disorders, weight loss, insomnia, asthma and hypertension. The behavioral symptoms are: work absenteeism, increased violent behavior, inability to have relationship, substance abuse and family problems. The emotional symptoms are marked by emotional detachment, impatience, irritability, difficulty for focusing and memorizing. Regarding defensive symptoms, manifestations include the denial of emotions, detachment from people and selective attention, anything to avoid a negative experience ${ }^{(5)}$.

Nursing as a profession, due to the fact it is based on a humanistic philosophy of care, having direct contact with feelings and problems of others, and because they establish an affective bond, even when that is not their will. Nursing is one of the professions most affected by Burnout Syndrome, progressively affecting the individual ${ }^{(13,14)}$. The development of Burnout syndrome among nursing students begins even before they receive their degree, it has been assigned to the expectations generated by them when enrolled the course ${ }^{(10)}$.

The difficulties experienced by students during their training are diverse such as: scheme of study, sensations experienced in the classroom and internship, helplessness sensation, caring for patients with terminal disease, ethical dilemmas, fear of acquiring infections during procedures, fear of making mistakes, deal with internal requirements, lack of leisure time, family, friends, personal needs, concerns with their own conflicts and emotional problems caused by contact with patients, questions and concerns about their ability to absorb all the information throughout the course, concerns about their economic gains in the present and in the future. In addition, many nursing students, besides the school workload, still divide time in a workload of 4-12 hours 
a day; others still have children and home to devote ${ }^{(3)}$. These are factors that lead to deterioration, because fatigue is common and the ability to concentrate is diminished, causing a low performance, leading to feelings of failure and emotional exhaustion, making students constantly exposed to various psychosocial stressors throughout their training.

As an academic who suffered and lived with classmates with the same dilemmas, fears and conflicts presented above, we questioned: are there cases of Burnout syndrome in senior undergraduate students of the nursing course? To answer this research question, we defined as objective of this study to evaluate the presence and the factors associated with Burnout Syndrome among academics taking into account the last year of undergraduate nursing course.

\section{METHODS}

Field research of exploratory type, descriptive and quantitative approach.

The field of action was a private university located in the metropolitan area of Porto Alegre, Rio Grande do Sul, which has undergraduate Nursing degree since 1984. From 2010, the course started having ten semesters and workload of 4080 hours. However, the study population followed the previous curriculum, eight semesters and workload of 3944 hours. As a feature of this university, students must enroll in a minimum of 12 credits per semester, which corresponds to three disciplines and not to the course week workload. Thus, the period of integration of the course is quite variable. However, in the last year of the course, all students are linked to curricular practical activities.

In 2011, the nursing program had 55 senior undergraduate students (seventh and eighth semesters). All of them were invited to participate, due to the fact they were involved with internship activities, which may contribute to the development of Burnout Syndrome among university students ${ }^{(5)}$. The establishment of inclusion criteria were: to be a senior undergraduate student of the Nursing course; accept to participate in the research; read and sign the Consent Form (CF). From the 55 invited students, 13 refused to participate of the research, so the final sample was composed of 42 students who agreed to participate. This represented a loss of $23.6 \%$ that could not be recovered, given the magnitude of the population and the refusal of the participants.

The instrument used for data collection was the Maslach Burnout Inventory Student Survey (MBI-SS), from Schaufeli, Leiter, Maslach and Jackson, with translation and adaptation for Brazil performed by Carlotto, Nakamura and Câmara ${ }^{(5)}$. It comprises 15 questions that are divided into three general scales, called: emotional exhaustion, depersonalization and personal accomplishment. We complemented this instrument with an identification sheet for obtaining the sample characteristics.

To collect data, professor's authorization, who were lecturing senior undergraduate students, was requested, so the researcher could perform the invitation and deliver the instrument, with the CF, and await the return of the questionnaire from those who agreed to participate. Then, the data were entered and processed in the statistical package for social sciences SPSS, version 17.0, later, frequencies were calculated for categorical variables and means for continuous variables. To compare the means of the independent samples, Student $t$ test was used. The results of the bivariate analysis were considered statistically significant when the p-value was $\leq 0.05$.

This research followed the guidelines of Resolution No. 196/96 of the National Health Council ${ }^{(15)}$, and the research project was approved by the Research Ethics Committee of the University in January 2011, with the number of Protocol No. 2011-005H.

\section{RESULTS}

The sample represented $76.3 \%$ of the population of nursing students enrolled in the last year of the course, in the $1^{\text {st }}$ semester of 2011, in the University studied. From the Students' participants in the research, $23(54.8 \%)$ were in the $8^{\text {th }}$ semester and $19(45.2 \%)$ in the $7^{\text {th }}$. It was found that $17(40.5 \%)$ were enrolled in University for 6 to 8 years, $11(26.2 \%)$, for 5 years; 9 $(21.4 \%)$, for 4 years; $5(11.9 \%)$ more than 8 years.

As sample characteristics of the 42 nursing students researched, we identified: $36(85.7 \%)$ were female, 21 $(50 \%)$ were aged $26-40$ years; $30(71.4 \%)$ had no partners; $29(69 \%)$ had no children; eight $(19 \%)$ had a child, three $(7.1 \%)$ two children and two $(4.8 \%)$ three children; $21(50 \%)$ lived with parents, $8(19 \%)$ lived alone and 13 (31\%) lived with a partner. Besides studying, 25 (59.5\%) had some sort of paid job, from these $17(40.5 \%)$ were working in the health area; of these, $14(33.3 \%)$ worked in private institutions and $12(28.6 \%)$ in the morning shift. Regarding the financing of studies, $21(50 \%)$ were responsible, $20(47.6 \%)$ earned the studies from their families and only one $(2.4 \%)$ had funding or scholarship.

Satisfaction with the course was predominant in 40 $(95.2 \%)$ of the academic participants, one $(2.4 \%)$ was not satisfied and one $(2.4 \%)$ chose not to answer this question. Along this journey, 18 (42.9\%) participants, at some point, have thought about quitting the course, $23(54.8 \%)$ never conceived the possibility of quitting and one $(2.4 \%)$ did not answer. The biggest concern of $32(76.2 \%)$ students was getting a job and the waiting time for this. 
As for Burnout index, we verified that personal accomplishment scale had the highest mean index (5.03), followed by emotional exhaustion (3.26) and, later, depersonalization with the lowest mean index (1.57) (Table 1).

Table 1. Burnout Scale mean index among senior undergraduate nursing students of a private university in the metropolitan region of Porto Alegre (Porto Alegre, 2011) $(n=42)$

\begin{tabular}{lccccc}
\hline Burnout & $\mathbf{n}$ & MinimumMaximum & Mean & DP \\
\hline $\begin{array}{l}\text { Emotional } \\
\text { Exhaustion }\end{array}$ & 42 & 0,60 & 5,80 & 3,26 & 1,59 \\
$\begin{array}{l}\text { Depersonalization } \\
\begin{array}{l}\text { Personal } \\
\text { Accomplishment }\end{array}\end{array}$ & 42 & 0,00 & 6,00 & 1,57 & 1,66 \\
\hline
\end{tabular}

The results showed that $42(100 \%)$ participants researched had high levels of personal accomplishment, 33
$(78.6 \%)$ had low levels of depersonalization, and in the emotional exhaustion category, students had the same mean high levels $21(50 \%)$ and mean low levels 21 (50\%), according to the cutting point by Likert scale (Table 2).

Table 2. Senior undergraduate nursing students of a private university in the metropolitan region of Porto Alegre by burnout scale levels (Porto Alegre, 2011) $(n=42)$

\begin{tabular}{lcc}
\hline Dimensions & $\begin{array}{c}\text { High levels }(\geq 3) \\
\mathbf{n}(\mathbf{\%})\end{array}$ & $\begin{array}{c}\text { Low levels (<3) } \\
\mathbf{n}(\mathbf{\%})\end{array}$ \\
\hline Emotional Exhaustion & $21(50 \%)$ & $21(50 \%)$ \\
Depersonalization & $9(21,4 \%)$ & $33(78,6 \%)$ \\
$\begin{array}{l}\text { Personal } \\
\text { accomplishment }\end{array}$ & $42(100 \%)$ & $0(0,0)$ \\
\hline
\end{tabular}

The evaluated variables were not associated with the burnout scales: emotional exhaustion, depersonalization and personal accomplishment (Table 3).

Table 3. Relationship between the burnout scales and qualitative variables of nursing students in the last year of a private university in the metropolitan region of Porto Alegre

\begin{tabular}{|c|c|c|c|c|c|c|c|c|c|c|c|c|}
\hline \multirow[t]{2}{*}{ Variables } & \multicolumn{4}{|c|}{$\mathbf{E E}$} & \multicolumn{4}{|c|}{$\mathrm{DE}$} & \multicolumn{4}{|c|}{ PA } \\
\hline & $\mathbf{X}$ & SD & $\mathbf{t}$ & p-value* & $\mathbf{X}$ & SD & $\mathbf{t}$ & p-value* & $\mathbf{X}$ & SD & $\mathbf{t}$ & p-value* \\
\hline \multicolumn{13}{|l|}{ Gender } \\
\hline Female & 3,39 & 1,54 & \multirow{2}{*}{1,27} & \multirow{2}{*}{0,21} & 1,45 & 1,60 & \multirow{2}{*}{$-1,20$} & \multirow{2}{*}{0,24} & 5,02 & 0,83 & \multirow{2}{*}{$-0,19$} & \multirow{2}{*}{0,84} \\
\hline Male & 2,50 & 1,79 & & & 2,33 & 1,96 & & & 5,09 & 0,91 & & \\
\hline \multicolumn{13}{|l|}{ Maritage status } \\
\hline Single & 3,37 & 1,53 & \multirow{2}{*}{0,73} & \multirow{2}{*}{0,46} & 1,46 & 1,49 & \multirow{2}{*}{$-0,71$} & \multirow{2}{*}{0,47} & 5,01 & 0,79 & \multirow{2}{*}{$-0,17$} & \multirow{2}{*}{0,86} \\
\hline In a stable union & 2,97 & 1,79 & & & 1,86 & 2,08 & & & 5,06 & 0,95 & & \\
\hline \multicolumn{13}{|l|}{ Children } \\
\hline Yes & 2,33 & 1,38 & \multirow{2}{*}{$-2,72$} & \multirow{2}{*}{0,09} & 1,64 & 1,98 & \multirow{2}{*}{0,16} & \multirow{2}{*}{0,87} & 5,08 & 0,89 & \multirow{2}{*}{0,29} & \multirow{2}{*}{0,77} \\
\hline No & 3,67 & 1,52 & & & 1,55 & 1,54 & & & 5,00 & 0,81 & & \\
\hline \multicolumn{13}{|l|}{ Paid Job } \\
\hline Yes & 2,95 & 1,54 & \multirow{2}{*}{$-1,56$} & \multirow{2}{*}{0,12} & 1,35 & 1,7 & \multirow{2}{*}{$-1,07$} & \multirow{2}{*}{0,28} & 4,98 & 0,88 & & 067 \\
\hline No & 3,72 & 1,59 & & & 1,91 & 1,6 & & & 5,09 & 0,76 & $-0,42$ & $-0,0 /$ \\
\hline Professional area & & & & & & & & & & & & \\
\hline Health & 2,98 & 1,72 & 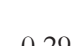 & 0 & 1,27 & 1,56 & & 060 & 4,95 & 0,85 & & \\
\hline Administrative & 3,17 & 1,73 & $-0,29$ & 0,10 & 1,6 & 2,29 & $-0,40$ & 0,08 & 5,28 & 0,83 & $-0,80$ & 0,59 \\
\hline Institution & & & & & & & & & & & & \\
\hline Public & 2,55 & 1,82 & 088 & 038 & 1,08 & 1,62 & 058 & 056 & 5,40 & 0,62 & 176 & 009 \\
\hline Private & 3,16 & 1,46 & $-0,00$ & (1), & 1,53 & 1,93 & (3), & (-), & 4,79 & 0,91 & & \\
\hline Semester & & & & & & & & & & & & \\
\hline Seventh & 3,11 & 1,51 & -065 & 0.52 & 1,97 & 1,95 & 175 & 089 & 5,02 & 0,82 & -009 & -0.92 \\
\hline Eighth & 3,43 & 1,7 & & & 1,09 & 1,10 & נו, & 0,0 & 5,04 & 0,85 & & \\
\hline Quit the course & & & & & & & & & & & & \\
\hline Yes & 3,35 & 1,62 & 026 & 070 & 1,87 & 1,65 & 108 & 028 & 4,86 & 0,86 & 150 & 014 \\
\hline No & 3,21 & 1,63 & 0,20 & 0,17 & 1,29 & 1,68 & 1,00 & 0,20 & 5,23 & 0,72 & $-1,00$ & 0,14 \\
\hline
\end{tabular}

EE - Emotional Exhaustion. DE - Depersonalization. PA - Personal accomplishment.

* Level of significance: $\mathrm{p} \leq 0.05$ 


\section{DISCUSSION}

By analyzing the profile of nursing students participating in this research, we found a sample predominantly female $(85.7 \%)$, with ages between $26-40$ years $(50 \%)$, agreeing with other studies with samples consisting predominantly of females by up to $95 \%$, with young people, relating care to women, reinforcing the historical relationship of Nursing ${ }^{(10,16-18)}$. In this research, it was evidenced that most of the sample $(71.4 \%)$ were single and $69 \%$ childless, in accordance to the characteristics presented in other studies with nursing students, designing a new Brazilian reality, in which women are choosing to marry and have children later, being priority professional training and integration of job market ${ }^{(10,18)}$.

By this study being conducted in a private university, it was found that only nine $(21.4 \%)$ students were able to perform their training within the period stipulated for completion of the undergraduate degree, ie in 4 years, others have opted to do less credits per semester, increasing the deadline to finish their training. As this is not a fulltime course, it allows students to combine study with paid jobs; it was found that from the 59.5\% of the sample performing paid activities, $40.5 \%$ were in health area. In a study published in 2009 about the students' characteristics in a private university ${ }^{(18)}$, the percentage of students performing paid jobs in health area, such as nursing staff was $48.7 \%$ of a population of 158 students. Another study ${ }^{(10)}$, with 102 nursing students, identified $51 \%$ of the sample performing paid activities, besides taking higher education. Authors of a study, when sought about the reason that led academics to choose the nursing course, found a large number already active in nursing, as technicians or assistants, justifying the degree choice for the following reasons: less selective course, allows professional promotion, improves scientific knowledge and consequently allows changing the status within the team ${ }^{(19)}$.

The major concern of senior undergraduate students is related to their first job as a nurse $(76.2 \%)$. This concern is not new, as it is the transition from student to professional status, source of stress in nurses recently-graduated; while they are anxious to start their professional activities, they also feel afraid of what they will face ${ }^{(20)}$.

Regarding the prevalence of Burnout in the studied sample, we found the general scale personal accomplishment reached the highest percentage (100\%), followed by the Emotional Exhaustion (50\%) and depersonalization $(21.4 \%)$, results that does not show cases of Burnout Syndrome, because it usually starts with high means of Emotional Exhaustion and depersonalization and low means in personal accomplishment. These results are similar to other studies with health area academics, which did not confirm the existence of Burnout in the sample. Researches ${ }^{(5,10)}$ performed with academics of all semesters of health area showed $71.56 \%$ presenting low levels of Emotional Exhaustion, 70.56\% low levels of Disbelief (in this study called Depersonalization). The data were similar, even studying senior undergraduate students.

The Emotional Exhaustion reached $50 \%$ of the sample, with mean of 3.26, indicating no Burnout. However, there is the possibility of developing the syndrome; though, students in this study appear to be protected by high mean of personal accomplishment.

In this research, it was evidenced that academics without paid jobs had higher mean of Emotional Exhaustion ${ }^{(3,72)}$ compared to those who were performing paid activities ${ }^{(2,95)}$; presenting higher mean in depersonalization, characteristic perceived by insensitivity and dehumanization caring for patients, and personal accomplishment. This result differed from another study conducted in Paraná, among students of the first period of a technical course in nursing, where students workers had higher exhaustion, depersonalization and lower personal accomplishment ${ }^{(21)}$. The differences identified may be due to the status of the occupation in both groups. The majority of the university students in this study (40.5\%) performed work activities related to the health context, representing the area of interest. In the case of students of technical courses, parallel paid jobs were related to other areas, given the impossibility of performing in health area, being a technician course student. This makes the job only a strategy to maintain studies.

An interesting result, shown in senior undergraduate students investigated with children, they had lower mean (2.33) in the category Emotional Exhaustion comparing to those without children (3.95). A similar result was observed in another study, in which the academics with children of health area had a mean of 2.26 in Emotional Exhaustion; and those without children had a mean of $3.05^{(5)}$. The fact was verified, in the academic practical experience, when a young mother of three children, was questioned how she could stand the whole journey of studies in theoretical disciplines, final paperwork, final internships plus her children; she answered that the greatest joy of her day was to get home and see the smile of the children waiting her, being able to attend them and being for them the most important person. This may indicate that childcare makes students to better distribute their time, being the contact with the child a source of gratification and a way to distance themselves from the stressors generated at the University.

For students who have thought about quitting the course, it was found a mean of 3.35 for Emotional Exhaustion, 1.87 in depersonalization and 4.86 in 
personal accomplishment, indicating dissatisfaction with the course and the desire to give up as reasons for students to develop their activities with less pleasure, unable to see the result of their efforts, making the study exhausting. Similar mean were found between academics of health area in 2004, with mean of 3.52 for Emotional Exhaustion, 2.09 in depersonalization and 4.53 in personal accomplishment ${ }^{(5)}$.

In this research students from the last semester had higher mean of Emotional Exhaustion(3.43), lowest in depersonalization (1.09) and highest in personal accomplishment (5.04) compared to students from the seventh semester. These results are expected, therefore, to be closer to the completion of the course, they are under pressure, with greater professor's demand to finish curricular internships, for the conclusion and presentation of final paperwork and anxiety to receive the diploma. At the same time, these students are insecure with the competitiveness of job market and it generates expectations about their career ${ }^{(10)}$.

\section{CONCLUSION}

A limitation of this study was the size of population investigated and the magnitude of the losses. In terms of the Burnout Syndrome, it might be possible to think the refusal as an indicator of the Syndrome. However, as the data collection was made in face to face with students, it was found that the refusal was more due to a lack of interest in participating than to the stress factors related to the end of the course, because the students who did not participated, kept doing their academic activities on a regular basis,

\section{REFERENCES}

1. Manarin AP, Bortoleto CB, Ferreira-Sae MC. Perspectivas do egresso de enfermagem frente ao mercado de trabalho. Ensaios e Ciência: C Biológicas, Agrárias e da Saúde. 2009; 13(1):93-105.

2. Brasil. Ministério da Educação e Cultura .Conselho Nacional de Educação. Resolução CNE/CES n.3, de 7 de novembro de 2001. Institui diretrizes Curriculares Nacionais do Curso de Graduação em Enfermagem [Internet]. Diário Oficial da República Federativa do Brasil, Brasília (DF); 2001 Nov 9 [citado em 2011 Jun 20]. Disponível em: http:/ / portal.mec. gov.br/cne/arquivos/pdf/Enf.pdf.

3. Nogueira-Martins MC. Humanização na saúde: a relação médico-paciente no microscópio. Rev Ser Médico. 2002; 18:27-9.

4. Schaufeli WB, Martínez IM, Pinto AM, Salanova M, Bakker AB. Burnout and engagement in university students. A CrossNational Study. J Cross Cult Psychol. 2002; 33(5):464-81.

5. Carlotto MS, Nakamura AP, Câmara SG. Síndrome de Burnout em estudantes universitários da área da saúde. Psico. 2006; 37(1):57-62. without showing any distinct characteristics of those who participated.

In this study, there were no cases of Burnout syndrome or risk factors for it. Students who have children have lower emotional exhaustion, not showing the relationship between education and children as a predisposing factor for Burnout. Another result that caught our attention was that the students who had no paid job presented higher mean of Emotional Exhaustion when compared to those performing paid activities.

There is a need to deepen the results. Therefore, it is suggested to conduct studies to investigate other variables related to academic life, covering the entire course of undergraduate nursing, so that it can provide comparisons between freshman students and seniors. Likewise, it would be interesting comparative studies among nursing students of public and private institutions, because the sample of this research is specific to a private institution, which may differ in the case of students of public universities.

It was found limited literature on the topic of Burnout syndrome among students, causing little comparison to the Brazilian reality and even internationally. However, investigation among academics of health area configured an important aspect in terms of promotion and prevention in occupational health, meeting the efforts of the Brazilian Ministry of Health regarding the humanization of health. Really tired people during professional training can represent less empathetic and attentive to the needs of users of health services during working life. Factor that contributes both to the professional's illness, as to the quality of care of the Brazilian health system.

6. Ritter RS, Stumm EM, Kircher RM., . Burnout analyses about professionals of an emergency unit of a general hospital]. Rev Eletr Enf [Internet]. 2009 [cited 2012 Set 10];11(2):23648. Portuguese. Available from: http://www.fen.ufg.br/ fen_revista/v11/n2/pdf/v11n2a02.pdf

7. Corral-Mulato S, Bueno SM. [Teachers in nursing and Burnout Syndrome: educating for health] CuidArte Enferm. 2009; 3(2):99-104. Portuguese.

8. Carlotto MS, Câmara SG. Análise da produção científica sobre a Síndrome de Burnout no Brasil. Psico. 2008; 39(2):152-8.

9. Codo W, organizador. Educação, carinho e trabalho. Petrópolis: Vozes; 1999. Burnout: síndrome da desistência; p.237-362.

10. Barboza JI, Beresin R. Burnout syndrome in nursing undergraduate students . Einstein. 2007; 5(3):225-30.

11. Cunha KW. A produção científica no Brasil nos anos de 2003 a 2008 sobre síndrome de Burnout e docência [dissertação]. Rio de Janeiro: Escola Nacional de Saúde Pública Sergio Arouca; 2009. 57p.

12. Kebian LV, Furtado CM, Paulino EF. A Síndrome de Burnout nos estudos de enfermagem: uma revisão bibliográfica. Rev 
Corpus et Scientia. 2010; 6(2): 51-61.

13. Jacques MG. Psicologia e trabalho. In: Guimarães LB. Ergonomia: tópicos especiais, qualidade de vida no trabalho, psicologia e trabalho. $4^{\mathrm{a}}$ Ed. Porto Alegre: FEENG/UFRGS/ EE/PPGEP; 2004. p. 1-14. (Série Monográfica)

14. Panizzon C, Luz AM, Fensterseifer LM. Estresse da equipe de enfermagem de emergência clínica. Rev Gaúch Enferm. 2008; 29(3):391-9.

15. Brasil. Ministério da Saúde. Conselho Nacional de Saúde. Resolução n. 196, de 10 de outubro de 1996. Dispõe sobre as diretrizes e normas de pesquisa envolvendo seres humanos. Diário Oficial da República Federativa do Brasil, Brasília(DF); 1996.

16. Nunes ZB, Negri G, Montejani GA, Gabrielli JM, Pelá NT. Prisioneiro do serviço da faculdade: o modo de vida do estudante de enfermagem trabalhador da enfermagem. Rev Centro Univ Barão de Mauá. 2001; 1(2):1-10.

17. Santos SR. [Analysis of the attitudes of nurses and nursing students concerning computer use in Paraíba, Brazil]. Rev
Latinoam Enferm. 2001; 9(6):56-61.Portuguese.

18. Vall J, Pereira LF, Friesen TT. [The nursing academic profile in a private university from Curitiba city]. . Cad Esc Saude [Internet]. 2009 [cited 2012 Set 10]; 2: [about 10p]. Available from: http://apps.unibrasil.com.br/revista/index.php/ saude/article/viewFile/232/183

19. Medina NV, Takahashi T. [Undergratuate nursing education as an option for nursing technicians and assistants]. Rev Esc Enferm USP. 2003; 37(4):101-8. Portuguese.

20. Mattosinho MM, Coelho MS, Meirelles BH, Souza SS, Argenta CE. [The world of work: some aspects experienced by professional nurses recently graduated]. Acta Paul Enferm. 2010; 23(4):466-71. Portuguese.

21. Osternack JV, Gonçalves LM, Amorim C. Avaliação da Síndrome de Burnout em estudantes do curso técnico em enfermagem de uma instituição privada na região de Curitiba [Internet]. Curitiba: PUCPR; 2007 [citado 2011 Jun 20]. Disponível em: http://www.pucpr.br/eventos/educere/ educere2007/anaisEvento/arquivos/CI-226-01.pdf. 